\title{
Anna Maryniak
}

Chair of Transport and Logistics, Faculty of Management, Poznań University of Economics and Business, Poland

\section{PRO-ECOLOGICAL ACTIVITIES IN A SUPPLY CHAIN AND PERFORMANCE ACHIEVED THROUGH THEIR IMPLEMENTATION}

\begin{abstract}
Nowadays in the world of science and business, the topic concerning the need to implement pro-ecological approach related to the movement of products in the supply chain and its impact on marketing, financial and logistic aspect is being increasingly addressed. However, there are few empirical studies that relate to Polish conditions or that present the issue in comprehensive manner. Therefore this study focuses both on strategic and operational management in the supply chain, and on the relations between consignor and consignee as well as on the subject of supply chain flow. The study aims to assess the impact of pro-ecological activities carried out in the supply chain for tested link as well as supply chain, and to assess the intensity of these activities.
\end{abstract}

Keywords: green supply chain, logistics, corporate social responsibility

\section{Introduction}

Assessment of economic and individual companies through the prism of gross domestic product (GDP) level, index of supply managers (PMI), consumer price index (CPI), trade balance, export volume - does not take into account social and environmental costs incurred by the dynamically developing economy. Thus it is important to create social and investment trust by demonstrating the involvement of entities engaged in sustainable (Czerwonka, 2012; Peylo, 2011) development and on the basis of its principles building market value (Hack, 2011). Along with the observed increase in the degree of internalisation of Polish companies (Jarosiński, 2014) and entering the international supply chains, the necessity to adjust to global 
standards in this area will keep mounting. Notwithstanding the current good economic situation of Poland, compared to other economies in the region, Poland's historical, economic and cultural legacy greatly impedes the development sustainable consumption patterns and motivation of business entities in the internal structures to act socially responsible in their internal structures, in their relation with the internal stakeholders of the supply chain as well as in the relation with stakeholders outside of the supply chain. Due to the above, the level of involvement in social activities of business entities is significantly lower than in highly developed world economies. This is reflected both:

- in the number of companies drawing social and environmental reports, (based on the Global Reporting Initiative - GRI, ISO 26000 and based on other guidelines and standards like AA 1000, ISO 14001, EMAS, SA 8000), as well as

- in the number of scientific publications that include Polish framework.

\section{Green supply chain}

Each of the pillars of sustainable operations is immensely significant. Among these are economic issues, e.g. concerning the transfer of operating costs to the weaker links in the chain, social problems like non-compliance with human and labour rights, as well as environmental issues, concerning care about environment and the quality of life of generations to come. This study focuses on Green Supply Chain Management (GSCM). For the purposed of the research presented in the article, it was assumed that "Green Supply Chain Management consists in: designing products and managing their flow up and down the supply chain by participating entities, with particular emphasis on the need to protect the environment" (Maryniak, 2017).

Based on the literature review, it can be stated, that subject of the green supply chain is the most popular among researchers from China, The United States, Taiwan, India, Great Britain and Malaysia. This conclusion was formulated on the basis of statistical analyzes of the number of GSCM publications contained in scientific databases (Maryniak, 2017). The scope of possible analyses within the green supply chain is impressive. For instance, this may be the topic of division of benefits resulting from the implementation of the green supply chain, the issue of reverse logistics, a strategic approach or systematic analysis (Fang, Zhang, 2018; Laari, Töyli, Ojala, 2017; Song, Gao, 2018; Zhao et al., 2018).

Smattering of academic positions from Central and Eastern European countries regarding the subject of GSCM hinders the production of comparative analyses of the activities undertaken by the enterprises and inhibits to determine the success resulting from these activities. There is few empirical researches concerning Poland (Fura, Surmacz, 2015; Ryszko, 2014; Tundys, 2018). There is an exceptionally large research gap in this area.

Available publications indicate positive relationship between activities and results (Luthra, Garg, Haleem, 2016; Tachizawa, Gimenez, Sierra, 2015). The lack of positive compounds is found only in the area of selected constructs (Laari, Töyli, Ojala, 2017; Masoumik, Abdul-Rashid, Olugu, 2015). Therefore, it is reasonable to hypothesize 
that undertaking such activity by the enterprises in Poland should lead to positive results both for the business environment and the companies themselves.

Test items for research were selected on the grounds of studies of the world's source literature, reflection on the current state of research and the information obtained through pilot studies. The whole range of topics, which can be included in the research, are particularly reflected in other reviews (Fang, Zhang, 2018; Kazancoglu, Kazancoglu, Sagnak, 2018; Islam, Karia, Soliman, 2017).

The analytical scheme consists of the two basic constructs: activities (undertaken for the sake of the environmental protection) and results (achieved through the implementation of pro-environmental activities), which content is presented in the next subchapter. Discovering the relations between the distinguished modules became the base of further research.

Original constructs and hypotheses were designed in a convention similar to the proposals of American, British, Chinese, Indian, Thai and Iranian scholars.

\section{Activities and results of GSCM}

In this study, the "activities" of GCSM are understood as all activities in the supply chain that take tangible form on (e.g. regarding modification of packaging, changes in inventory levels in individual links) as well as intangible activities (e.g. Creating codes of conduct with suppliers, controlling whether indirect suppliers adhere to environmental requirements) aimed at environmental protection.

As a result of the research, 37 test items, namely, GSCM activities were selected. They were grouped into the following constructs:

- "suppliers - controlling activities" activities carried out by suppliers of a "control” nature are associated (e.g. auditing the suppliers in the field of environmental compliance, requiring environmental certificates from suppliers),

- "suppliers - decision making activities" activities carried out by suppliers but not of a "control" nature are associated (e.g. whether, if possible, local suppliers are selected, cooperation with suppliers for which environmental criteria are important),

- "consignees - controlling activities" activities of a "control" nature, required by the consignees, are associated (e.g. obtaining environmental certificates required by consignees, subjecting to environmental audits required by recipients),

- "consignees - decision making activities" activities concerning consignees but not of a "control" nature are associated (e.g. if possible selecting local consignees, cooperation with consignees for whom environmental criteria are important),

- "logistics" activities related to transport, inventory and storage are associated (e.g. using environmentally friendly transport means, optimizing inventory management also in the context of its environmental impact),

- „supply chain” test items concerning system solutions that support GSCM are related (e.g. risk analysis in the supply chain in the context of natural environment, implementation of cargo tracking system along the entire transport route),

- "product and packaging - the structure" activities that affect the change of product or packaging directly, in order to protect the environment are related 
(e.g. elimination of hazardous substances from packaging and increasing their resistance to damage),

- "product - supply chain” activities that are carried out jointly with the supply chain participants and that relate to product or packaging are related (e.g. customer survey on the possibility of introducing more pro-environmental products to the market, consulting suppliers on the subject of possibility of changing packaging.).

The benefits achieved through pro-environmental activities in the supply chain are defined as „results” (GSCM) in this study. The results of GCSM are analysed both in the context of material aspects: environmental, operational and economic, as well as intangible aspects.

The individual entries presented in the conceptual model constituted by the test items consist of the results concerning:

- market conditions (e.g. improvement of the image, increase in the market share) - "market”,

- improvement of relations in the supply chain (e.g. with suppliers and customers) - „relations in the supply chain”,

- supply chain management (e.g. reduction of inventory levels, improvement of supply configuration) - "supply chain management",

- environmental impact (e.g. reduction of water usage and soil pollution.) - „environment",

- financial aspects (e.g. profit growth, improvement of overall level of profitability) - „finance",

- improvement of processes and products (e.g. increasing their innovation) "processes and products",

- material management (e.g. reduction of their usage and use of waste) - „material management",

- business management (e.g. better exploitation of potential/resources, investment growth) - „business management”.

For the purpose of the research, production enterprises were selected, because they are related to the operators of both the lower and the upper supply chain. As a result, it was possible for us to look at the environmental issues from a wider research perspective. The subjects of the research were big and medium-sized enterprises, classified according the Central Statistical Office to section $\mathrm{C}$ divisions 10-32 9 (in Poland).

Respondents were asked to respond to a series of statements by selecting:

- what pro-environmental activities are undertaken by companies in the supply chain,

- what results are obtained in the connection with the introduction of pro-environmental activities.

Answers were given using the five-level Likert scale, where $1=$ strongly agree, 2 agree 3 = neither agree nor disagree, $4=$ disagree, $5=$ strongly disagree.

In the research process, a hypothesis was formulated according to which: activities related to implementation of GCSM by companies are positively correlated with results generated for their stakeholders. 
Altogether, after rejecting defective questionnaires, 73 companies were accepted for the research. The drawing of companies were made on the basis of records purchased from the GUS (Central Statistical Office) ${ }^{4}$.

The consistency of the construct examined in the study was assessed using the Cronbach's Alpha coefficient, descriptive statistics were carried out together with the Kolmogorov-Smirnov test and correlation analysis using the Spearmen rho coefficient. The significance level of $p=0.05$ was determined. In order to consider the relationship's strength and the direction of dependence of variables contained in the GSCM model, correlation coefficients of r-Pearson and rho-Spearman were used.

All correlations proved to be statistically significant. The strongest relationships were identified between pro-environmental activities and results concerning processes and products, business management, market and relations in the supply chain (Table 1).

Table. 1. Analysis of relationships between internal and external results and activities: a comparison of correlation coefficients together with the values of significance

\begin{tabular}{|l|l|c|c|}
\cline { 3 - 4 } \multicolumn{2}{c|}{} & Pro-environmental activities & $\mathrm{p}$ \\
\hline \multirow{2}{*}{ Internal results } & Processes and products & rho $=0,564$ & $<0,001$ \\
\cline { 2 - 4 } & Business management & $\mathrm{r}=0,515$ & $<0,001$ \\
\hline \multirow{2}{*}{ External results } & Market & $\mathrm{r}=0,513$ & $<0,001$ \\
\cline { 2 - 4 } & Relations in supply chain & rho $=0,528$ & $<0,001$ \\
\hline
\end{tabular}

Source: (own study based on the survey results)

Obtained results yield inducement to develop pro-environmental policy along the entire supply chain and justify the need to motivate enterprises to this type of activity. The reflection on the results of research on Polish companies may encourage and mobilize to develop GSCM entities from the same region - countries of Central and Eastern Europe, where such projects are still not popular.

In the following stage of the research, it was diagnosed which groups of environmental activities undertaken in the supply chain are the most popular, and those that are the most often used within a given construct (Figures 1 and 2).

Among the most popular pro-environmental activities are these, which are related to product packaging and logistics, so they regard operational issues. We can expect that along with the development of GSCM, more and more activities will be undertaken in a strategic dimension.

4 Theresearch was carried out within the framework of the „Zrównoważony łańcuch dostaw" grantno. 51109 -2-51 granted by the UE Poznań. The grant was launched in 2015, concluded in February, 2018. 


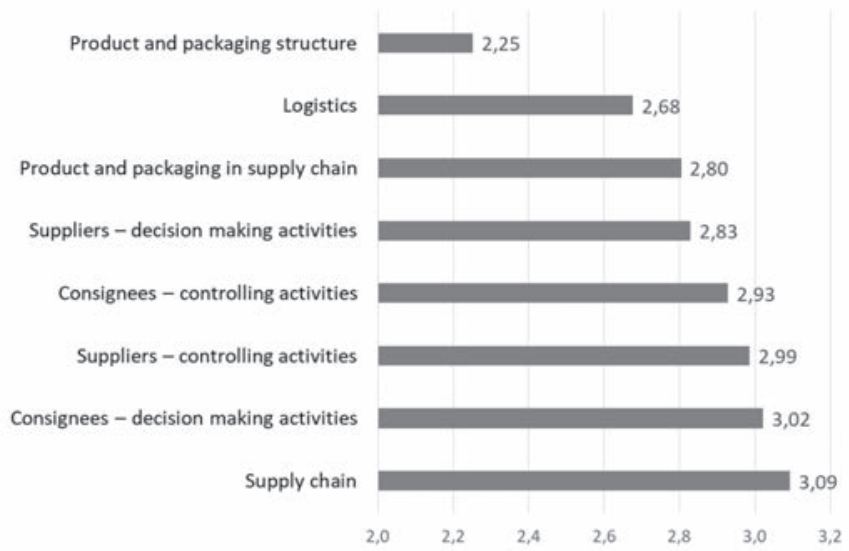

Figure 1. Frequency of environmental activities in the supply chain Source: (own study based on the survey results)

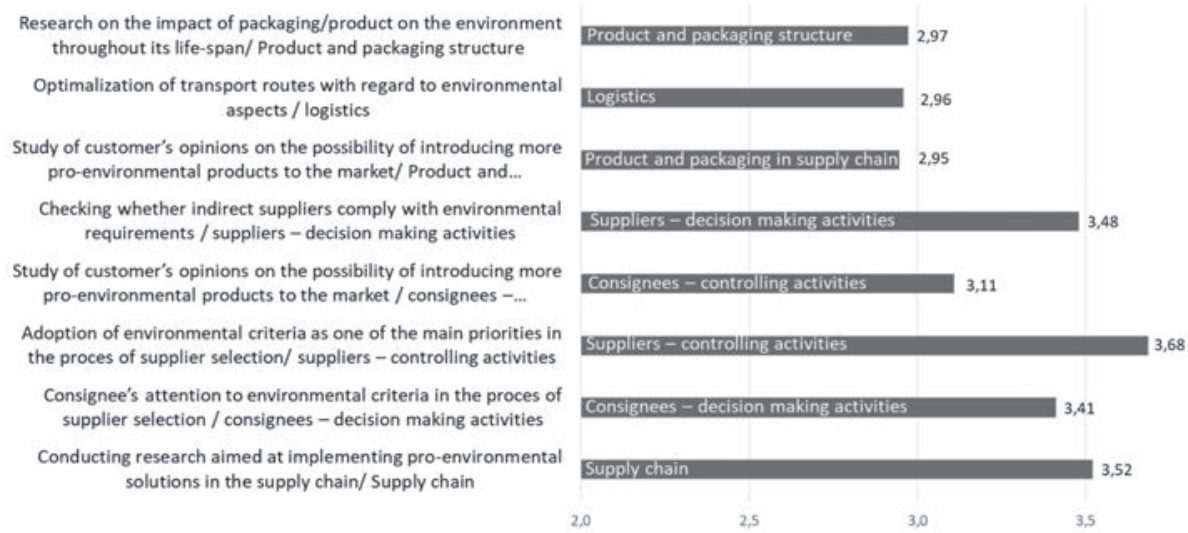

Figure 2. The most popular environmental activities in the supply chain, within individual construct

Source: (own study based on the survey results)

By the virtue of the fact, that enterprises primarily try to implement "green" solutions at the level of the product itself and logistics, while to the smallest extent are implemented solutions covering different links of the supply chain, it can be assumed that green supply chain management in Polish production entities is at the initial stage, because they regard operational activities, which are far simpler than the strategic ones. The repetition of the research on a bigger sample of enterprises will allow for confirming the conclusions through the attempt of hypothesis falsification.

On the basis of obtained data it can be also stated that, first of all, all the results obtained through the implementation of pro-environmental solutions concern materials management and environment. Therefore it can be concluded that the results obtained are mainly of a pro-savings nature (Figure 3). 


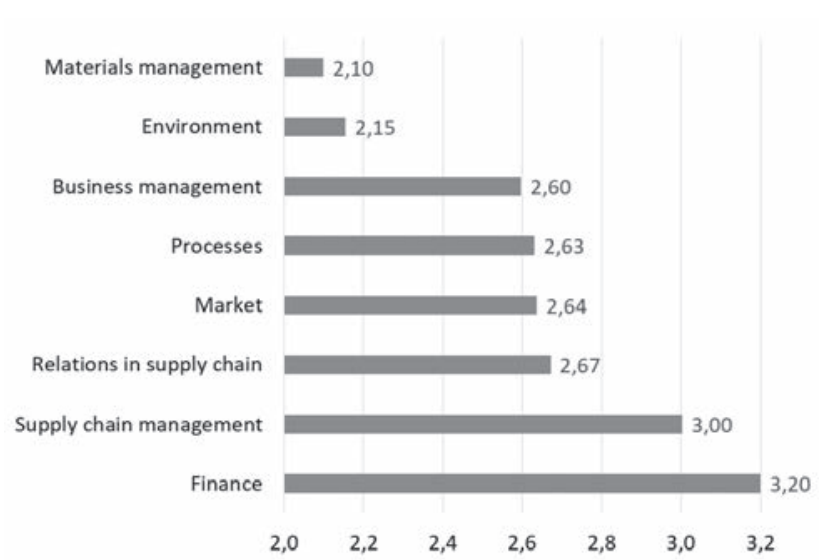

Figure 3. Results obtained as a result of implementation of pro-environmental activities in the supply chain

Source: (own study based on the survey results)

The most frequent results for given construct are shown in Figure 4.

The smaller the mean was, the more often the respondents mentioned such results, which were the effects of the implementation of pro-environmental activities.

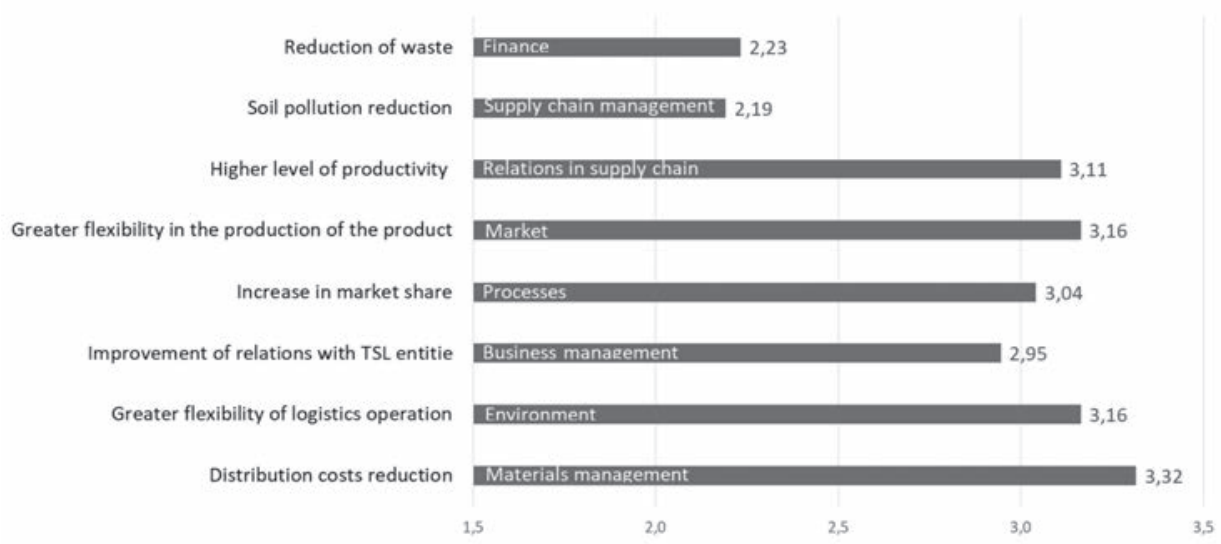

Figure 4. Frequency of results in environmental supply chain Source: (own study based on the survey results)

As a result of the undertaken GSCM activities, the enterprises firstly observe the reduction of soil pollution and waste reduction. 


\section{Conclusions}

Participants of supply chains whose links are located in Poland, should follow world trends and requirements set by foreign corporations, and strive to create the right climate for the development of green supply chains.

Based on the obtained data, it can be concluded that the implementation of pro-environmental activities has a positive impact on both internal and external stakeholders, but the scale of current implementation is low.

The fact that the smallest effects of GSCM implementation were achieved in the area of finance and in the area of supply chain management may indicate the low development level of the discussed activities. The observed popular pro-savings activities may theoretically negate the above, however, some spectacular financial effects will be probably visible after some longer time. This relates to the scale of GSCM implementation as well as its scope and intensity.

\section{References}

Czerwonka, M. (2012), The concept of socially responsible investing (SRI) in Poland, Journal of Management and Financial Sciences, 5 (8), pp. 76-90.

Fang, Ch., Zhang, J. (2018), Performance of green supply chain management: A systematic review and meta-analysis, Journal of Cleaner Production, 183, pp.1064-1081.

Fura, B., Surmacz, T. (2015), Znaczenie ósmej zasady zarządzania jakością w budowaniu zielonych łańcuchów dostaw, Logistyka, 2, pp. 748-754.

Hack, S. (2011), Sustainability, Innovation and Information Technology as Sources of Value Generation, Journal of Management and Financial Sciences, 4 (5), pp. 16-35.

Islam, S., Karia, N., Soliman, M. (2017), A review on green supply chain aspects and practices, Management \& Marketing, 12 (1), pp. 12-36.

Jarosiński, M. (2014), Characteristics of Polish Firms' Internationalisation Processes. In Knežević, B., Wach, K. (Eds.), International Business from the Central European Perspective, University of Zagreb Publishing House, Zagreb, pp. 43-52.

Kazancoglu, Y., Kazancoglu, I., Sagnak, M. (2018), A new holistic conceptual framework for green supply chain management performance assessment based on circular economy, Journal of Cleaner Production, 195, pp. 1282-1299.

Laari, S., Töyli, J., Ojala, L. (2017), Supply chain perspective on competitive strategies and green supply chain management strategies, Journal of Cleaner Production, 141, pp. 1303-1315.

Luthra, S., Garg, D., Haleem A. (2016), The impacts of critical success factors for implementing green supply chain management towards sustainability: An empirical investigation of Indian automobile industry, Journal of Cleaner Production, 121, pp. 142-158.

Maryniak, A. (2017), Zarządzanie zielonym tańcuchem dostaw, Wydawnictwo Uniwersytetu Poznańskiego, Poznań.

Masoumik, S.M., Abdul-Rashid, S.H., Olugu, E.U. (2015), The Development of a Strategic Prioritisation Method for Green Supply Chain Initiatives, PLoS ONE, 10(11), e0143115, pp. 1-33.

Peylo, B.T. (2011), Integration of Sustainability into Modern Portfolio Theory, Journal of Management and Financial Sciences, 4 (6), pp. 85-109.

Ryszko, A. (2014), Otoczenie przedsiębiorstwa a zarządzanie zielonym łańcuchem dostaw - wybrane zagadnienia, Logistyka, 6, pp. 2059-2066, 14660-14668.

Song, H., Gao, X. (2018), Green supply chain game model and analysis under revenue-sharing contract, Journal of Cleaner Production, 170, pp. 183-192. 
Tachizawa, E.M., Gimenez, C., Sierra, V. (2015), Green supply chain management approaches: drivers and performance implications, International Journal of Operations E Production Management, 35 (11), pp. 1546-1566.

Tundys, B. (2018), Problematyka wyboru dostawcy w zielonym łańcuchu dostaw - studium analityczne, Prace Naukowe Uniwersytetu Ekonomicznego we Wrocławiu, Wrocław, 505, pp. 263-277.

Zhao, Y., Cao, Y., Li, H., Wang, S., Liu, Y., Li, Y., Zhang, Y. (2018), Bullwhip effect mitigation of green supply chain optimization in electronics industry, Journal of Cleaner Production, 180, pp. 888-912.

\section{Corresponding author}

Anna Maryniak can be contacted at: anna.maryniak@ue.poznan.pl 